\title{
SEROPREVALENCE OF LEPTOSPIROSIS AND ITS ASSOCIATION WITH REPRODUCTIVE AND PRODUCTIVE PARAMETERS FROM BUFFALO POPULATION OF RAJANPUR AND MUZAFFARGARH DISTRICTS OF PAKISTAN
}

\author{
M. Ijaz, A. Ghaffar, A. Ali, S. H. Farooqi, Y. R. Khan and A. I. Aqib \\ Department of Clinical Medicine and Surgery, University of Veterinary and Animal Sciences, 54600-Lahore \\ Corresponding author Email: mijaz@uvas.edu.pk \\ The paper was presented in International Buffalo Congress 2019, February 18-20, Lahore, Pakistan \\ https://doi.org/10.36899/JAPS.2020.1.0007 \\ Published online January 02,2020
}

\begin{abstract}
Leptospirosis is one of the important infectious diseases adversely affecting the fertility and reproductive parameters of domestic animals. The current study was aimed to investigate the sero-prevalence of leptospirosis and its association with reproductive and productive parameters from buffalo population of Rajanpur and Muzaffargarh districts of Punjab, Pakistan. A total of 386 buffalo serum samples were analyzed for anti-leptospira antibodies through indirect ELISA using "Anti-Leptospira IgG kit". The information regarding disease determinants were captured in questionnaire. Univariable and multivariable logistic regression models were used to correlate the potential risk factors with the disease dynamics. The results revealed an overall $12.69 \%$ prevalence of leptospirosis in both of the study districts, with higher percentage reported in district Rajanpur followed by Muzaffargarh presenting 20.72 and $04.66 \%$ prevalence at significant difference $(p \leq 0.05)$, respectively. The univariable analysis found district, estrus repetition, body condition score and history of retained placenta as significant candidates $(p \leq 0.05)$ while, multivariable logistic regression presented district, gender of animal and estrus repetition as the key risk factors (Odds Ratio $>1$ ). The study concluded that leptospirosis is prevalent in study districts and there is association of assumed risk factors with disease dynamics, which demands early installment of control strategies before the disease become unleashed.
\end{abstract}

Key words- Leptospirosis, Sero-prevalence, Risk factors, Buffalos.

\section{INTRODUCTION}

Leptospirosis is one of the important infectious diseases which adversely affect the fertility and reproductive parameters of domestic animals (Saglam et al., 2008). It is emerging infectious disease of livestock with zoonotic significance (Koet al., 2009). The etiological agent responsible for this disease occurrence is a pathogenic bacterium of genus Leptospira (Fornazari et al., 2012). This disease affects not only the milk production of animals but also causes several reproductive disorders like stillbirth, abortion and birth of weak calves leading to tremendous financial losses to small holder farming communities (Sanhueza et al., 2013; Ndengu et al., 2017). Due to availability of favorable environment for the transmission of Leptospira, this disease is prevalent in developing countries (Bharti et al., 2003). In bovines, this disease leads to abortion after several weeks' infection which is usually not associated with an obvious ailment (Bahari et al., 2011). This disease has an adverse influence on the reproductive tract of bovines leading to compromised production and ultimate economic losses (Bomfim and Koury, 2006). The exact data regarding the economic losses due to the abortions from leptospirosis is limited. It is very difficult to determine the exact extent of economic losses attributed to leptospirosis. An outbreak of this malady in Argentina for a period of 1 year resulted in losses of up to US $\$ 150,000$ for deaths of 100 calves, treatment and vaccination of 1300 survivors (Draghi et al., 2011). While in France, the estimated cost of losses due to this disease in cattle herds was from US $\$ 97$ to 2611 per aborted cow (Ayral, 2013). However, the cost of problems besides abortion which are common and frequent has not yet been estimated. The climatic conditions such as warm temperatures, soil $\mathrm{pH}$ and the high rainfall, are favorable for the existence of Leptospira and also for the long term preservation of its pathogenicity (Martins and Lilenbaum, 2015; AndreFontaine et al., 2015).

The definite diagnosis and identification of leptospirosis is by isolation technique but the detection by anti-leptospiral antibodies is also practiced. The isolation of bacteria is time consuming and it also demands livability of pathogen along with the ability of bacteria to grow on culture media, thus serological method is obliged for the detection purpose worldwide (Brandao et al., 1998). Reported prevalence of leptospirosis in various animal species across different countries of world ranges between 2.00-46.00\% (Leal-Castellanos et al., 2003; Faria et al., 2007). This wide variation might be related to several factors such as climate, animal species, time of 
the year, and method of investigation. Due to the presence of promising transmission circumstances, leptospiral infection is emerging health malady in developing countries (Ahmad, 2000). The transmission of infection has been reported by direct contact with uterine discharges, urine, placenta, and sexual contact with affected animals but indirect way of transmission of disease that involves the contact with contaminated environment (Bharti et al ., 2003).

In this context the current study was aimed to investigate the sero-prevalence of leptospirosis and its association with reproductive and productive parameters from buffalo population of Rajanpur and Muzaffargarh districts of Pakistan.

\section{MATERIALS AND METHODS}

Study design: The study area of current project comprised of two flood hit districts-Muzaffargarh and Rajanpur (Figure 1) - of south Punjab province of Pakistan. The study districts are livestock rich and animals are the main source for livelihood of more than $2 / 3^{\text {rd }}$ population. The district Muzaffargarh is having four tehsils, namely Muzaffargarh, Kotaddu, Alipur and Jatoi, whereas, district Rajanpur has three tehsils, namely Jampur, Rajanpur and Rojhan.

A total of 386 blood samples (193 from each study district) were collected aseptically from buffalos which were not having vaccination history against leptospirosis, by convenient sampling technique. From Muzaffargarh district sampling was conducted in such a way that 6 samples were collected from each village; from on tehsil four union councils were selected and from each union council two villages were further selected for sampling which comprised 192 blood samples, one additional sample was taken from kotaddu tehsil. Similarly from Rajanpur district 8 blood samples were collected from each village, from one tehsil four union councils were selected and from each union council two villages were further selected for sampling which comprised 192 blood samples, an additional sample was taken from Rojhan tehsil. The data regarding the risk factor analysis was collected in questionnaire.

Blood sampling: All the blood samples were collected aseptically from the jugular veins of buffalos individually and transferred to non-EDTA coated vacutainers separately. The collected blood samples were then placed undisturbed at room temperature for 30 minutes to clot formation. The samples were centrifuged within 2 hours of collection in order to prevent hemolysis and serum was decanted into sterile Eppendorf tubes by sterile technique. The collected serum samples were shipped to Medicine Laboratory Department of Clinical Medicine and Surgery, University of Veterinary and Animal Sciences
(UVAS), Lahore maintaining the cold chain. The samples were kept at $4{ }^{\circ} \mathrm{C}$ till further processing.

Processing of samples by serology: The serum samples were processed by indirect (Enzyme linked immunosorbent assay) ELISA using (Alpha Diagnostic, international, USA) "RecomBac Bovine Anti-Leptospira LipL32 IgG kit" following the manufacturer instructions.

Statistical analysis: The data regarding the summary of risk factors was analyzed by logistic regression analysis. Firstly, all the study variables were analyzed by univariable analysis, the variables which produced $\mathrm{P} \leq 0.2$ were further analyzed by logistic regression analysis to find out the potential risk factors. The analysis was conducted on SPSS Version 20.00.

\section{RESULTS}

The study has detected $12.69 \%$ of the buffalo's positive for anti-leptospiral antibodies in both of the study districts. The buffaloes of district Rajanpur presented higher prevalence $(20.72 \%)$ as compared to district Muzaffargarh's (04.66\%). Results have presented study districts to be statistically associated $(p \leq .05)$ with leptospiral sero-prevalence, the buffaloes of Muzaffargarh district are at higher risk $(\mathrm{OR}=8.464$; $\mathrm{CI}=3.307-21.665)$ towards Leptospira exposure than buffaloes of Rajanpur district. Gender of the animals was also found to be a key risk factor, having significant $(p \leq .05)$ impact on Leptospira sero-prevalence. The female buffaloes are more than two times as likely $(\mathrm{OR}=2.009 ; \mathrm{CI}=0.470-8.584)$ to be seropositive than those to male buffaloes. Data analysis revealed that the buffaloes having history of estrus repetition are at higher risk $(\mathrm{OR}=8.244 ; \mathrm{CI}=1.4849-46.899)$ as compared to those who are not having history of estrus repetition towards anti-leptospiral antibodies.

The assumed risk factors like study district from which sampling was conducted, gender of animals, mastitis history, history regarding repetition of estrus, body condition score, history of retained placenta, previous history of any treatment given to animals, history of blood in milk and reduction in milk production, physiological and immune status of animal and abortion history were statistically analyzed (Table 1). To find out the association of the key risk factors with the seropositivity, all the risk factors were analyzed through univariable and multivariable logistic regression analysis. The gender of animal, history of mastitis, reduction in milk production, previous history of treatment given to the animals, status of animals, history of blood in milk and abortion history were not proved to be significant candidates towards anti-leptospiral antibodies.

Initially, twelve variables were included in statistical analysis (Table 1), the variables which produced $p \leq 0.2$ by univariable analysis were further 
analyzed by multivariable analysis to find out the potential risk factors, so six variables were included in final multivariable analysis model (Table 2), from which three were found to be the potential risk factors towards leptospiral sero-positivity. So, multivariable logistic regression presented buffaloes from Muzaffargarh district, female and animals having history of repeat breeding to be associated with the occurrence of disease dynamics. The history of retained placenta and immune status of the animals were proved to be significant candidates on the basis of univariable analysis but nonsignificant on the basis of multivariable logistic regression model.

Table 1.Univariable analysis association and descriptive statistics in Buffaloes.

\begin{tabular}{|c|c|c|c|c|}
\hline Variable & Categories & Positive (\%) & Negative & $p$-Value \\
\hline \multirow{2}{*}{ District } & Muzaffargarh & $09(04.66)$ & 184 & \multirow{2}{*}{$0.001^{*}$} \\
\hline & Rajanpur & $40(20.72)$ & 153 & \\
\hline \multirow{3}{*}{ Gender } & Female & $44(12.08)$ & 320 & \multirow{2}{*}{0.180} \\
\hline & Male & $05(22.73)$ & 17 & \\
\hline & Yes & $06(08.00)$ & 69 & \multirow{3}{*}{0.358} \\
\hline \multirow[t]{3}{*}{ Mastitis } & No & $10(13.16)$ & 66 & \\
\hline & NA & $33(14.04)$ & 202 & \\
\hline & Yes & $08(05.13)$ & 148 & \multirow{3}{*}{$0.001^{*}$} \\
\hline \multirow{3}{*}{ Estrus repetition } & No & 09 (09.47) & 86 & \\
\hline & NA & $32(23.70)$ & 103 & \\
\hline & Normal & $41(18.06)$ & 186 & \multirow{3}{*}{$0.001^{*}$} \\
\hline \multirow[t]{2}{*}{ Body Condition Score } & Thin & $07(05.26)$ & 126 & \\
\hline & Emaciated & $01(03.85)$ & 25 & \\
\hline \multirow{3}{*}{$\begin{array}{l}\text { Reduction in milk } \\
\text { production }\end{array}$} & Yes & $27(12.27)$ & 193 & \multirow{3}{*}{0.273} \\
\hline & No & $14(17.50)$ & 66 & \\
\hline & NA & $08(09.30)$ & 78 & \\
\hline \multirow{3}{*}{$\begin{array}{l}\text { Previous history of } \\
\text { treatment given }\end{array}$} & Yes & $31(13.42)$ & 200 & \multirow{3}{*}{0.600} \\
\hline & No & $18(11.61)$ & 137 & \\
\hline & Pregnant & $31(13.25)$ & 203 & \\
\hline \multirow[t]{2}{*}{ Animal status } & Non pregnant & $07(12.28)$ & 50 & \multirow[t]{2}{*}{0.913} \\
\hline & NA & $11(11.58)$ & 84 & \\
\hline \multirow{3}{*}{$\begin{array}{l}\text { Immune status against } \\
\text { major diseases }\end{array}$} & Non Vaccinated & $22(09.91)$ & 200 & \multirow{3}{*}{0.057} \\
\hline & Vaccinated & $27(16.46)$ & 137 & \\
\hline & Yes & $06(12.00)$ & 44 & \\
\hline \multirow[t]{3}{*}{ History of blood in milk } & No & $38(12.33)$ & 270 & \multirow[t]{3}{*}{0.717} \\
\hline & NA & 05 (17.85) & 23 & \\
\hline & Yes & $43(12.11)$ & 312 & \\
\hline \multirow{2}{*}{ Abortion history } & No & 04 (18.18) & 18 & \multirow[t]{2}{*}{0.530} \\
\hline & NA & $02(22.22)$ & 7 & \\
\hline \multirow{3}{*}{$\begin{array}{l}\text { History of retained } \\
\text { placenta }\end{array}$} & Yes & $02(15.38)$ & 11 & \multirow{3}{*}{$0.001^{*}$} \\
\hline & No & $13(06.37)$ & 191 & \\
\hline & NA & $34(20.12)$ & 135 & \\
\hline
\end{tabular}

${ }^{*} p \leq 0.05=$ significant difference

Table 2. Final Model of Multivariable logistic regression identifying the potential risk factors in the studied predictors.

\begin{tabular}{|c|c|c|c|c|c|c|c|}
\hline Variable & Category & S. $\mathbf{E}^{* * *}$ & Wald & P-value & $\begin{array}{l}\text { Odds } \\
\text { Ratio }\end{array}$ & $\begin{array}{c}\text { Lower } \\
\text { C.I (95\%) }\end{array}$ & $\begin{array}{c}\text { Upper C.I } \\
(95 \%)\end{array}$ \\
\hline District & $\begin{array}{l}\text { Muzaffargarh } \\
\text { Rajanpur }\end{array}$ & .480 & 19.840 & .000 & 8.464 & 3.307 & 21.665 \\
\hline Gender & $\begin{array}{l}\text { Female } \\
\text { Male }\end{array}$ & .741 & .887 & .346 & 2.009 & .470 & 8.584 \\
\hline Estrus repetition & $\begin{array}{l}\text { Yes } \\
\text { No }\end{array}$ & $\begin{array}{l}.887 \\
.834 \\
\end{array}$ & $\begin{array}{l}5.656 \\
1.296 \\
\end{array}$ & $\begin{array}{l}.017 \\
.255 \\
\end{array}$ & $\begin{array}{l}8.244 \\
2.585 \\
\end{array}$ & $\begin{array}{c}1.449 \\
.504 \\
\end{array}$ & $\begin{array}{l}46.899 \\
13.263 \\
\end{array}$ \\
\hline
\end{tabular}




\begin{tabular}{|c|c|c|c|c|c|c|c|}
\hline & NA & & & & & & \\
\hline Body Condition & Normal & 4.730 & .030 & .094 & .011 & .792 & 1.086 \\
\hline Score & $\begin{array}{l}\text { Thin } \\
\text { Emaciated }\end{array}$ & .455 & .500 & .470 & .053 & 4.210 & 1.118 \\
\hline Immune status & $\begin{array}{l}\text { Non Vaccinated } \\
\text { Vaccinated }\end{array}$ & .516 & 2.379 & .123 & .451 & .164 & 1.241 \\
\hline History of & No & 968 & .692 & .406 & .447 & .067 & 2.980 \\
\hline retained placenta & $\begin{array}{l}\text { Yes } \\
\text { NA }\end{array}$ & 1.168 & 3.157 & .076 & .126 & .013 & 1.239 \\
\hline
\end{tabular}

${ }^{* *}$ Standard error

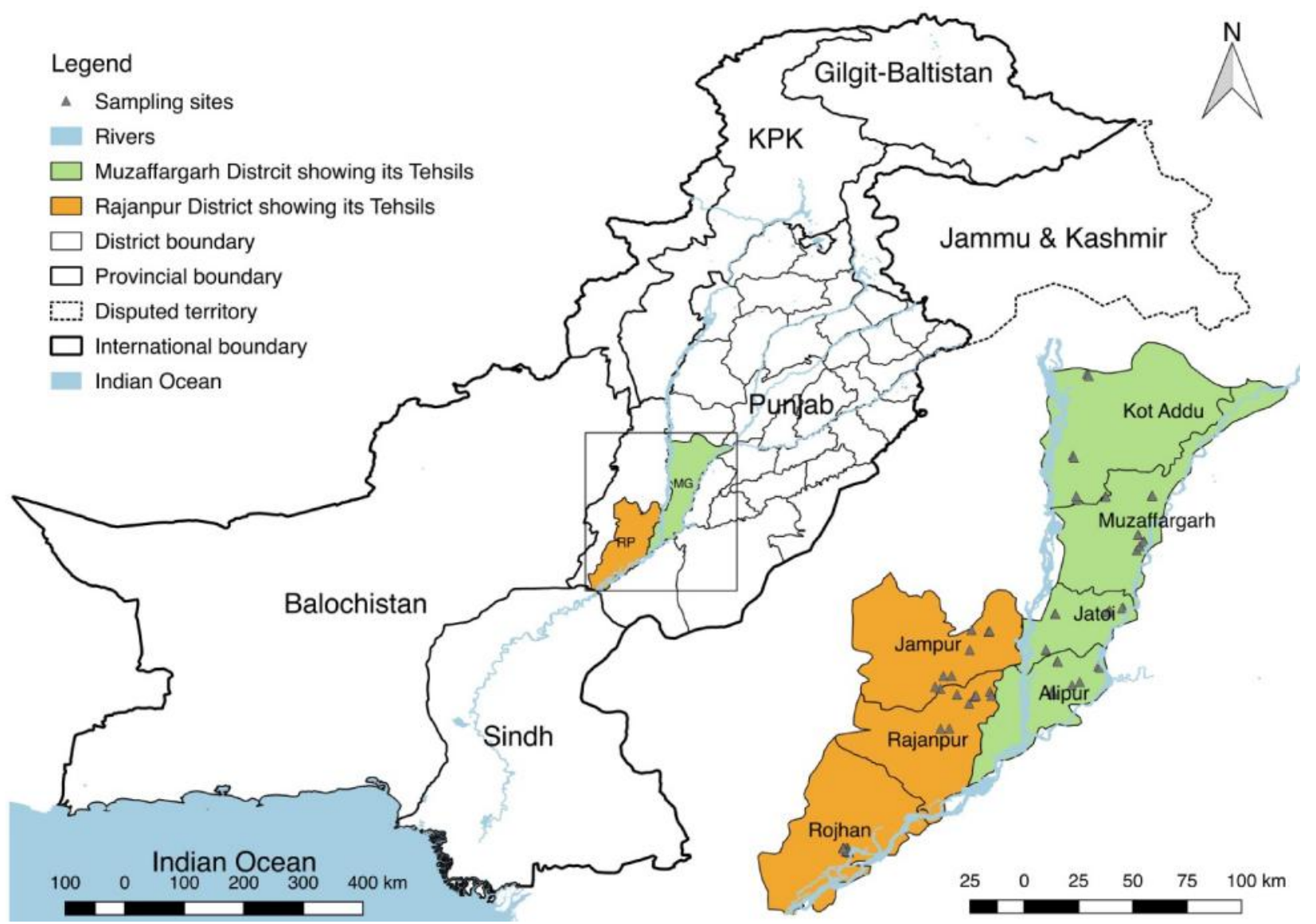

Figure 1. Map showing the study districts.

\section{DISCUSSION}

Most of the infectious diseases are proved to be serious threat to the livestock (Yilmaz et al., 2016; Elhaig et al., 2016; Qayyum et al., 2016). Leptospira infection frequently remains clinically silent but is found positive on serological assays (Hassanpour et al., 2011).

Letospira's sero-prevalence has been reported in human as well as in domestic animals of Pakistan by rapid microscopic slide agglutination test (Ahmad, 1987). There are also few studies which have reported this pathogen in dogs (Saleem et al., 2013a), horses (Sohail et al., 2016), bovine (Ijaz et al., 2018a, b; Islam et al., 2019) and human population (Saleem et al., 2013b; Sohail et al., 2018) of Pakistan. This study shows the association of leptospira sero positivity with reproductive parameters which is supported by Boqvist et al. (2002). This study was conducted in buffaloes of flood hit zones of Pakistan, and flood water is supposed to be positively associated with the occurrence of disease. These findings are justified by Bandino et al. (2015) and Sohail et al. (2016) as they proposed floods and rain fall both strongly associated with sero-prevalence of Leptospira.

The current study revealed $12.69 \%$ of the buffalo's positive for anti-leptospiral antibodies. The reported sero-prevalence of leptospira in buffaloes of Uganda (Atherstone et al., 2014) and Malaysia (Bahaman et al., 1987) is $42.39 \%$ and $31 \%$, respectively which is 
quite higher than that of India in which prevalence was reported 2.8\% (Schoonman and Swai, 2010). The variation in prevalence might be due to distinct geographies, different management and husbandry practices and sampling strategies.

A significant difference was observed between the Leptospira sero-prevalence and study districts. In this study buffaloes of district Rajanpur presented higher prevalence of anitleptospiral antibodies than the animals from Muzaffargarh district. These types of results are in agreement with the findings of Sohail et al. (2016) who also have reported significant difference of Leptospira sero-prevalence and study area in horses of Pakistan. The difference in prevalence in both of the study districts might be due to different production and rearing systems. Prevalence of leptospirosis was higher in buffaloes having history of abnormally repeating estrus. Leptosira infection is found to be strongly associated with estrus repetition in cattle (Libonati et al., 2018). Female were found to be at higher risk of getting the disease as compared to males. These findings are also in line with findings of Sohail et al. (2016), who has reported higher sero-prevalence of Leptospira in female horses of Pakistan. It might be due to pregnancy stress or lactation stress in females.

Although non-significant in this study, but Leptospira infection has been found to be associated with abortions in animals (Prescott et al., 1988). If reproductive system's infection is involved it could result in a "storm of abortions" causing considerable losses in form of meat and milk yield reductions (Tooloei et al., 2008). Infertility, shown as delayed calving intervals and increased services per conception, is associated with this infection (Guitian et al., 1999; Dhaliwal et al., 1996). The exact pathogenesis is not clearly understood, however apparently the evidence for the presence of this pathogen in the oviduct and uterus of infected animals might interferes with the implantation of embryo or some other early pregnancy events (Grooms, 2006). The body condition score of animals was proved to be significant candidate on the basis of univariable analysis but was not found to be risk factor on the basis of final logistic regression model which resembled with the findings of Parvez et al. (2015).

The study concluded that the buffalo population of Rajanpur and Muzaffargarh districts is having considerable amount of anti-leptospiral antibodies and leptospirosis affects the animals silently. The study demands the scheduled vaccination program to control this zoonotic malady.

Acknowledgements: The authors acknowledge the Higher Education Commission (HEC) of Pakistan for funding the current project no. 20-4310/NRPU/R \& $\mathrm{D} / \mathrm{HEC} / 14 / 593$. The authors are thankful to Medicine Laboratory and Department of Clinical Medicine and
Surgery, University of Veterinary and Animal Sciences, Lahore for the provision of Laboratory facilities for smooth run of this project

Conflict of interest: Authors declare no conflict of interest.

\section{REFERENCES}

Ahmad, I (2000). Correlation of leptospiral, antibodies to the non-functional ovaries \& biometrical observations in the slaughtered buffaloes \& cattle. M.Sc Dissertation, Department of Theriogenology, College of Veterinary and Animal Sciences, Lahore. http://agris.fao.org. p96

Ahmed, I.P (1987). Serological studies on leptospirosis in Pakistan. J. Pakistan Med. Assoc., 37(9): 233236.

Andre-Fontaine, G., F. Aviat and C. Thorin (2015). Waterborne leptospirosis: survival and preservation of the virulence of pathogenic Leptospira spp. in fresh water. Curr. Microbiol., 71: $136-142$

Anwar.K., N. Khan and M. Mujtabullah.(2013). Sero prevalence of leptospirosis in aborted dairy cattle in Peshawar district suburb, Khyber Pakhtunkhwa Pakistan. Int. J. Curr. Microbiol. Appl. Sci., 2(8): 73-78.

Atherstone, C., K. Picozzi and G. Kalema-Zikusoka (2014). Sero-prevalence of Leptospira hardjo in cattle and African buffalos in southwestern Uganda. Am. J. Trop. Med. Hyg., 90(2): 288290

Ayral, F (2013). La leptospirosedans les cheptels bovins laitiers en France: impactéconomique de l'infection. Bulletin GTV 69: 61-67.

Bahaman, A.R., A.L. Ibrahim and H. Adam (1987). Serological prevalence of leptospiral infection in domestic animals in West Malaysia. Epidemiol. Infect., 99(2): 379-392.

Bahari, A., G. Abdollahpour, A. Sadeghi-Nasab, S. Sattari-Tabrizi, M. Yavari and B Dadmehr (2011).A serological survey on leptospirosis in aborted dairy cattle in industrial farms of Hamedan suburb, Iran. Iran J. Vet. Res., 12: 337-339.

Bandino, J.P., A. Hang and S.A. Norton (2015). The infectious and noninfectious dermatological consequences of flooding: a field manual for the responding provider. Am. J. Clin. Dermatol., 16 (5): 399-424.

Bharti, A.R., J.E. Nally, J.N. Ricaldi, M.A. Matthias, M.M. Diaz, M.A. Lovett, P.N. Levett, R.H. Gilman, M.R. Willig, E. Gotuzzo and J.M. Vinetz (2003). Peru-United States Leptospirosis 
Consortium. Leptospirosis: a zoonotic disease of global importance. Lancet Infect. Dis., 3: 757 771

Bomfim, M.R.Q and M.C. Koury (2006). Evaluation of LSSP-PCR for identification of Leptospira spp. In urine samples of cattle with clinical suspicion of leptospirosis. Vet. Microbiol., 118: 278-288.

Boqvist, S., H.T.V. Thu, I. Vågsholm and U. Magnusson (2002).The impact of Leptospira sero-positivity on reproductive performance in sows in southern Viet Nam. Theriogenology., 58(7): 1327-1335.

Brandão, A.P., E.D. Camargo, E.D. da Silva, M.V. Silva and R.V. Abrão (1998).Macroscopic agglutination test for rapid diagnosis of human leptospirosis. J. Clin. Microbiol., 36(11): 31383142

Dhaliwal, G.S., R.D. Murray, H. Dobson, J. Montgomery and W.A. Ellis (1996). Reduced conception rates in dairy cattle associated with sero-logical evidence of Leptospira interrogans serovar hardjo infection. Vet. Rec.,139:110-114

Draghi, M.G., B. Brihuega, D. Benítez, J.M. Sala, G.M. Biotti, M. Pereyra, A. Homse and L. Guariniello (2011). Leptospirosis outbreak in calves from Corrientes Province,Argentina. Rev. Argent. Microbiol., 43: 42-44.

Elhaig, M.M., A. Selim, M.M. Mahmoud and E.K. ElGayar (2016). Molecular confirmation of Trypanosoma evansi and Babesia bigemina in cattle from lower Egypt. Pakistan Vet. J. 36: 409-414.

Faria, M.T., D.A. Athanazio, E.A.G. Ramos, E.F. Silva, M.G. Reis and A.I. Ko (2007). Morphological alterations in the kidney of rats with natural and experimental Leptospira infection. J. Comp. Pathol., 137: 231-238.

Fornazari, F., R.C. Da Silva, V.B. Richini-Pereira, H.E. Beserra, M.C. Luvizotto and H. Langoni (2012). Comparison of conventional PCR, quantitative PCR, bacteriologica culture and the warthin starry technique to detect Leptospira spp. in kidney and liver samples from naturally infected sheep from Brazil, J. Microbiol. Methods., 90: 321-326.

Grooms, D.L (2006). Reproductive losses caused by bovine viral diarrhea virus and leptospirosis. Theriogenology., 66(3): 624-628.

Guitian, J., M.C. Thurmond and S.K. Hietala (1999). Infertility and abortion among first-lactation dairy cows seropositive or sero-negative for Leptospira interrogans serovar hardjo. J. Am. Vet. Med. Assoc.,215: 515-518.

Hassanpour, A., M. Imandar, G.R. Abdollahpour and M. Mahsayekhi (2011). Sero-prevalence of Leptospiral Infection in Ewes in Khoy, Iran. Adv. Environ. Biol., 5: 2033-2038
Ijaz, M., S. N. Abbas, S. H. Farooqi, A. I. Aqib, G.A. Anwar, A. Rehman, M.M. Ali, K. Mehmood and A. Khan (2018b).Sero-epidemiology and hemato-biochemical study of bovine leptospirosis in flood affected zone of Pakistan. Acta.trop., 177: 51-57.

Ijaz, M., S. N. Abbas, S. H. Farooqi, A. I. Aqib, P. Bakht, A. Ali, A. Ghaffar and S. Saleem (2018a). SeroEpidemiology of Bovine Leptospirosis and Associated Risk Factors in a Flood Affected Zone of Pakistan. Pakistan Vet. J., 38(2): 179183.

Islam, S., W. Shehzad, A. A. Bajwa, M. Imran, M. Y. Zahoor, M. Abdullah, M. I. Rashid, K. Ashraf, Y. F. Chang, A. Nadeem, M. Younas, S. A. M. Bukhari, M. M. Hassan, Z. I. Qureshi and R. Akhtar (2019). Molecular Detection of Brucellosis, Leptospirosis and Campylobacteriosis by Multiplex PCR and Screening by ELISA Assays in Buffalo Breeding Bulls. Pakistan Vet. J., http://dx.doi.org/10.29261/pakvetj/2019.092

Ko, A.I., C. Goarant and M. Picardeau (2009). Leptospira: the dawn of the molecular genetics era for an emerging zoonotic pathogen. Nat. Rev. Microbiol., 7: 736-747.

Leal-Castellanos, C.B., R. Carcia-Suarez, E. GonzalezFigueroa, J.L. Fuentes-Allen and J. EscobedoDe La penal (2003). Risk factors and the prevalence of leptospirosis infection in a rural community of Chiapas, Mexico. Epidemiol. Infect., 131: 1149-1156

Libonati, H.A., G.B. Santos, G.N. Souza, F.Z. Brandao and W. Lilenbaum (2018). Leptospirosis is strongly associated to estrus repetition on cattle. Trop. Anim. Health and Prod., 50(7): 1625 1629.

Martins, G and W. Lilenbaum, 2015.Comments of environmental conditions for the maintenance of Leptospira in tropical scenarios. Curr. Microbiol., 71: 624-625

Ndengu, M., M. Garine-Wichatitsky, D.M. Pfukenyi, M. Tivapasi, B. Mukamuri and G.Matope (2017). Assessment of community awareness and risk perceptions of zoonotic causes of abortion in cattle at three selected livestock-wildlife interface areas of Zimbabwe. Epidemiol. Infect., 6: $1-16$.

Parvez, M.A., M.A.M., Prodhan, M.A., Rahman and M.R. Faruque (2015). Seroprevalence and associated risk factors of Leptospira interrogans serovar hardjo in dairy cattle of Chittagong, Bangladesh. Pakistan Vet. J., 35(3): 350-354.

Prescott, J. F., R.B. Miller, V.M. Nicholson, S.W. Martin and T. Lesnick (1988). Seroprevalence and 
association with abortion of leptospirosis in cattle in Ontario. Can. J. Vet. Res., 52(2): 210

Qayyum, A., J. A. Khan, R. Hussain, M. Awais, N. Ahmad and M.S. Khan (2016). Investigation of milk and blood serum biochemical profile as an indicator of subclinical mastitis in Cholistani cattle. Pakistan Vet. J., 36: 275-279.

Saglam, Y.S., Z. Yener, A. Tenur and E. Yalcin (2008). Immunohistochemical detection of leptospiral antigens in cases of naturally occurring abortions in sheep. Small Rum. Res., 74: 119122.

Saleem, M. H., M.S. Khan, A.Z. Durrani, A. Hassan, M. Ijaz and M. M. Ali (2013b). Leptospirosis: An emerging zoonosis in Pakistan. Pakistan J. Zool., 45(4)

Saleem, M. H., M.S. Khan, M. A. Khan, M. A. Khan, M. Ijaz, A. Sardar and K. Mehmood (2013a). Sero surveillance of canine leptospirosis under different climatic conditions in and around Lahore, Pakistan. Pakistan Vet. J., 33: 241-243.

Sanhueza, J.M., C. Heuer, D. West (2013). Contribution of Leptospira, Neosporacaninum and bovine viral diarrhea virus to fetal loss of beef cattle in New Zealand. Prev. Vet. Med. 112: 90 -98.
Schoonman, L., and Swai, E. S. (2010). Herd-and animallevel risk factors for bovine leptospirosis in Tanga region of Tanzania. Trop. Anim. Health and Prod., 42(7): 1565-1572.

Sohail, M. L., M.S. Khan, M. Ijaz, O. Naseer, Z. Fatima, A.S. Ahmad and W. Ahmad (2018). Seroprevalence and risk factor analysis of human leptospirosis in distinct climatic regions of Pakistan. Acta trop., 181: 79-83.

Sohail, M.L., M.S. Khan, M. Avais, M.Y. Zahoor, M. Ijaz, A. Ullah, Z. Fatima, O. Naseer, I .Khattak and S. Ali (2016). Sero-prevalence of Leptospira spp. in Horses of Distinct Climatic Regions of Punjab, Pakistan. J. Equine Vet. Sci., 44: 82-89.

Tooloei, M., G. Abdollapour, H. Karimi and A. Hasanpor (2008).Prevalence of serum antibodies against six leptospira serovars in sheep in Tabriz, North-western Iran. J. Anim. Vet. Adv., 7: 450455

Yilmaz, R., I.T. Cangul, K. Onat, A. Akkoc, M.O. Ozyigit and E. Akdesir (2016) Histopathological, immunohistochemical and bacteriological characterization of Mycoplasma bovis pneumonia in cattle. Pakistan Vet. J., 36: 316-321. 